\title{
Land matters and rural development: 2009 (2)
}

\section{General}

Grave concerns were raised as to whether the overall land reform programme embarked upon in 1994 has really been successful (Van der Walt 'Hoekom grondhervorming misluk' Burger (2009-08-28) 28; Barnard 'Zuma moet ingryp oor Distrik Ses' Burger (2009-08-14) 12). Specific concern exists over the slow pace of redistribution of agricultural land and the number of farmers who, after having received farm land, were unable to farm their land productively (Cillie 'Sukkelboere verloor grond' Sake Burger (2009-0818) 1). In this regard government has indicated that it will make available additional financial support, totalling R146 million, to about 500 farmers in dire need of funds in order to proceed with farming.

Government placed a moratorium on the purchase of new farms until all settled claims are finalised. In August 2009, the Deputy General of the Department of Rural Development and Agrarian Reform indicated that the support of farmers, organised agriculture and industry would be necessary to restore existing farms 'destroyed by years of administrative bungling' 'less would be spent on land acquisition and more on developing existing state-owned land' (Legalbrief Today (2009-08-11) www.legalbrief.co.za).

In his State of the Nation Address in June 2009, the President announced that government would introduce a comprehensive programme to build economic and social infrastructure. He also indicated that a comprehensive rural development strategy linked to land reform, agrarian transformation and food security would be developed and implemented (http: //www.info. gov.za/speeches/son/index.html).

According to the 2009-2012 Strategic Plan of the Department of Rural Development and Land Reform (http://www.dla.gov.za/publications/), seven key priority areas have been identified, namely:

(a) the integration of land and agrarian reform in the development of a sustainable rural development policy;

(b) to increase the number of land transfers under the land redistribution programme in order to meet the $30 \%$ objective;

(c) to expedite the outstanding complex rural restitution claims;

(d) to finalise policy and the legislation aimed at the regulation of ownership of land by foreigners; 
(e) to finalise the Land Use Management Bill;

(f) to finalise the necessary regulations that will enable the implementation of the Communal Land Rights Act 18 of 2004; and

(g) to develop programmes for the empowerment of vulnerable groups such as women, youth and people living with disabilities.

This note will discuss the most important measures and court decisions pertaining to land restitution, land redistribution, land reform, housing, land use planning, deeds, minerals, property tax, agriculture and rural development. $^{1}$

\section{Land restitution}

The Commission of Land Claims validated two land claims, one in the Kruger National Park and the other in Mapungubwe. Mapungubwe and 26 other farms are involved in the land claim of the Machete Royal family. It is, at this stage, uncertain whether the land will be transferred to the community. Approximately 900000 ha of land is claimed in the Kruger National Park by 37 communities and this will include the areas of Skukuza, Letaba, UnderSabie and the Numbi Gate. The Land Claims Commission cannot restore the land in the Kruger National Park. As it happens, the budget for the restitution of land rights for 2009 has already been depleted. It is unclear whether there is sufficient land available to provide the communities with alternative land should these claims be successful. It seems that the communities are making claims to the title deeds of the lands involved and to the co-management of the Kruger National Park. (See in this regard Tempelhoff 'Grondeise laat regering sweet' Beeld (2009-08-31) 16.)

The Land Claims Commission referred 200 cases back to the landowners, because they suspected that the land prices were inflated. Land in Mpumalanga and Limpopo was, for example, sold for approximately R7000 per hectare, while in KwaZulu-Natal the estimated price was between R25 000 and R33 000 per hectare (Legalbrief (2009-04-15)).

\section{Notices}

Several notices were published, (eg, Gauteng and North West (Nokeng Tsa Taemane 3; Ngaka Modiri Molema District; Bojanala 6; Moshaweng 1; Kungwini 1; Johannesburg 1; no indication of District 6); Eastern Cape (Mqanduli 1; Middelburg 3; Keiskammahoek 1; Cala 4; Cacadu 138; Lady Frere 1; Ngqamakhwe 1; Ngqeleni 1; Mthatha 18; King Williams Town 3; Flagstaff 2; Tabankulu 2; Tsolo 1; Qumbu 2; Bizana 1; Whitlesea 15; Port Elizabeth 1; Fort Beaufort 1; Aberdeen 7; East London 5; Cofimvaba 1; Ugie 1; Sterkspruit 3; Mount Fletcher 2; Amathole 1; Queenstown 1; Centane 1; Uitenhage 6; Kidd's Beach 4); Western Cape (Greater Cape Town area 27; Ceres 1; Grabouw 1; Matroosfontein 1;

${ }^{1}$ This note covers the most important literature, legislation and court decisions for the period 2009-04-15 to 2009-09-04. 
Stellenbosch 3; Mossel Bay 2; Bonnievale 1; Worcester 1; Oudtshoorn 2; Beaufort West 2; Drakenstein 1; Malmesbury 1; Montagu 1; Simon's Town 1; Swellendam 1; Tulbagh 1; Barrydale 2; Still Bay 1; various areas in the Western Cape 3); KwaZulu-Natal (Pietermaritzburg 1; Lions River 1; Inanda 1; Weenen 2; Klip River 1); Mpumalanga (Lekwa Local Municipality 1; Nkangala 10; Gert Sibande 10; Steve Tshwete 1; Mahlabathini 1); Limpopo (Sekhukhune 1; Capricorn 3) and Free State and Northern Cape (Gordonia 4; Namaqualand District Municipality 1; Frances Baard District Municipality 1; Siyanda 2; Parys 1; Emakhazeni 1). In the Limpopo Province 2 amendment notices were published and in KwaZuluNatal 5; Mpumalanga 7 and in the Free State and Northern Cape 1. One withdrawal notice was published in KwaZulu-Natal. In General Notice 1057 (in GG 32462 of 2009-08-07) the Land Commissioner of the Eastern Cape listed the reasons why she withdrew a land claim notice. It is the first notice of this kind. She indicated that research showed that the claim was based on a pre-19 June 1913 dispossession.

\section{Case Law}

In the course of 2005 an ex parte order was granted in chambers by the LCC prohibiting the 'demolishing, structuring or reconstructuring, developing or rezoning' of land being claimed by the Alexandra Land and Property Association (ALPOA). This interim order was granted against the Executive Mayor of Greater Johannesburg who, in an official capacity and in the process of urban renewal, intended to demolish the structures that had been erected. Three years after the interim order was granted an application was lodged on an urgent basis to rescind the interim prevention order. ALPOA $\vee$ The Department of Land Affairs and Four Other Respondents (LCC 82/04 decided 2009-01-13) deals with the rescission application. The value of the judgment handed down illustrates the particular approach that is generally followed in the LCC, namely that it is not a court of technicalities, but rather a court of substance (para 12). It also emphasises that in socio-economic litigation, considerations other than the purely legal, may in certain circumstances come into play. Here the court, per Bam JP, highlighted that there were various legal options available to the respondents instead of the present application. These options included immediately taking action when the interim order was granted by way of amending the directives, disputing the urgency of the matter and contesting the merits (para 4). Apart from these options, there further remained the possibility of utilising section 35(11) of the Restitution of Land Rights Act 22 of 1994 to launch rescission proceedings (para 5). Instead, a period of three years of inaction followed. In the light of these considerations, the court found that the application for rescission failed to present a reasonable and acceptable explanation for the excessive delay in launching the application. In addition to this, it would seem as if the City complied with the interim order in that the structures were spared, and indeed were not demolished or removed. Acquiescence barred the rescission (para 11). 
The court found that the general approach followed by the City and other respondents was problematic. The court was satisfied that other options, instead of litigation, were still available to the parties. An offer, for example, was placed on the table enabling the City to proceed with its renewal and development programme without being a threat to the landowners of the application. That option was never explored. Judge President Bam found the 'application was misconceived and counterproductive' (para 18), and that '[t]he attitude of intransigence exhibited was quite unprofessional. Socio-economic litigation requires a lot more circumspection than was shown in this case' (para 19). In the light of these circumstances in their entirety, the court departed from its tradition of not granting orders for costs. Apart from the considerations already mentioned, the court went on to underline that ALPOA had to go to great lengths to garner financial resources, whereas the City had public funds at its disposal. 'Considerations of equity and fairness, therefore, justify a departure from the general practice not to award costs' (para 20).

\section{Land redistribution}

A report was submitted in Parliament which stated that approximately R71 billion will be needed to ensure that $15 \%$ of land is transferred to Black ownership by 2014. By 2009, only $5 \%$ has been transferred. Various reasons are proffered for the lack of progress (Legalbrief (2009-07-02)). The Minister of Agriculture indicated that the Department would take over the mortgage bonds of 283 emerging farmers who stood to lose their land to the Land Bank. Collectively, the farmers owe R232 million. The Department would also take over the production loans of 30 farmers and only after it becomes clear that there is no production on the farms, would the farms be offered to other emerging farmers (Groenewald 'Land Banks dramatic turnabout' Mail \& Guardian (2009-08-21-17) 10; Cillié 'Sukkelboere verloor grond' Sake24 (2009-08-18) 1).

The Land Bank also addressed corruption in its midst and showed a profit for the first time in many years (De Waal 'Landbank skud korrupsienes en amptenare val uit' Sake24 (2009-09-04) 1). The Minister in the Office of the President indicated that in future no distinction would be made between white and black owned land, and that the emphasis would be on productive land (De Waal 'Grond nie meer "wit" of "swart" sê Trevor' Sake24 (2009-0715) 1). Currently, $49 \%$ of the land transferred to emerging farmers is not used productively (Duvenage ' $49 \%$ van swart grond nog nie produktief benut' Sake24 (2009-08-12) 2).

\section{Land reform}

\section{Extension of Security of Tenure Act 62 of 1997 (ESTA)}

In Gate Development Ltd v Mahlangu, (LCC 103/08 decided 2009-03-04) the phrase 'established practice' in relation to the burial rights of occupiers 
under ESTA was scrutinised. It was argued that in the present circumstances there no longer existed an established practice of burial on the property concerned (para 9). Several burials had taken place on the land in question since 1971. Apparently the persons in charge of the property were reluctant to agree to more burials on the land some time prior to 2003 owing to their increasing frequency and the attendant health risks. The burials that did take place on the farm in 2006 and 2007 were carried out without consent. When the persons in charge complained, they were overruled by the Department of Land Affairs.

Thus, the question before the court was whether there existed an established practice. This entailed the landowner (or person in charge) routinely giving permission for burials (para 12). The court interpreted an established practice to mean the following: if there is a burial site in existence, though not perhaps utilised with the frequency or regularity of an urban cemetery and even intermittently, an established practice exists in the context and intention of the Act (para 13). The legislature inserted section $6(2)(d A)$ in order to provide for the creation of further graves. Irregularity or inconsistency does not negate the obligation to provide a further burial site. The right to bury is not wiped out by temporary non-use. In the present instance, the deceased had entered into an agreement with the landowner that neither he nor his descendents would demand to be buried on the farm. On testimony of the landowner this agreement was concluded previously when the deceased approached the landowner for permission to bury his parents, at which time the permission was granted in return for the waiver of his (the deceased's) rights. At the hearing, however, it was submitted that the deceased did not know the contents of the document and that he would not have conceded to being buried in strange lands (para 15). The factual dispute was not addressed by the court, but the focus was on whether the waiver of burial rights was affected by section 25 of ESTA that stated that waivers of rights by occupiers were void except if it was permitted in terms of the Act or when incorporated in an order of court. Courts are not bound to agreements insofar as the agreement seeks to limit any rights of an occupier, but should have regard to them. The historical background and motivation for the Act requiring that waiver agreements be sanctioned under careful scrutiny by a court was again confirmed (para 21). In this context the court found that the persons in charge of the farm were legally bound to allow the burial of the deceased on the farm on the basis of section 2(2)(dA).

In Minister of Land Affairs $v$ Mphuthi (Case number 3028/06 (OFSPD) decided 26 February 2009) the land in question was state-owned land, namely Portion 77 of Farm 1903 in the area of Harrismith. The respondents came to occupy the farmland in 1998 in the mistaken belief that it formed part of Portion 76, which they had leased, and later purchased from the state. Thus, when they moved onto the land and into the homestead, they thought the land was within the boundaries of the portion they leased. On 
that basis they effected improvements to the house and also added two additional rooms. It later transpired that the relevant portion of the farm was separate from the portion they actually leased (and later purchased) and was in reality leased to another, who testified to that fact. They have thus been in unlawful occupation of that portion of land since 1998. In July 2006 an eviction application was lodged after they failed to reach a settlement. The respondents believed they were in lawful occupation and were only convinced otherwise when they saw aerial photographs and a survey report in April 2007. Despite that, they remained in occupation and instead, raised the issue of their being occupiers under ESTA.

The judgment dealt mainly with the issue of whether the respondents were occupiers for the purposes of ESTA. If that were indeed the case, the high court would not generally have jurisdiction to adjudicate, except if the parties consented to its jurisdiction. Accordingly emphasis was placed on the concept of 'occupier' and how one became an occupier as well as the consequences thereof. It was underlined that ESTA was aimed at protecting a particular class of impecunious rural tenant (para 12). As the initial occupation was not on a lawful basis and because it did not coincide with consent, the respondents did not meet the first requirement for becoming occupiers under ESTA (para 15). On the facts it was furthermore clear that the farm was utilised for commercial farming enterprises, something specifically excluded in the definition of occupier (para 14). Accordingly, it was found that the respondents were not occupiers for the purposes of ESTA. Concerning the eviction application the Court found that: ' $t$ the applicant has met all the requirements of proving entitlement to the relief sought under common law'. Although the respondents do not qualify as occupiers under ESTA and the conclusion reached by the court in that regard is correct, the judgment is problematic for many reasons. In the first instance, it does not state what the status of the respondents is. They are certainly unlawful occupiers resulting in the legal principles relating to unlawful occupiers becoming relevant. Different sets of rules apply for different categories of unlawful occupiers. The court has already disqualified the ESTA set of measures, but did not consider any of the other categories of legislative measures also impacting on unlawful occupiers. It is not possible that the court can grant an eviction order under the common law. This approach ignores section 4(1) of PIE and the watershed judgment in the Ndlovu $v$ Ngcobo and Bekker $v$ Jika (2002 4 All SA 348 (SCA)). If the common law is applied, and not PIE, only two requirements come into play, namely: (a) that the applicant is the owner of the property, and (b) that the respondent is in occupation thereof. This approach does not allow for the consideration of all relevant circumstances, as required by section 26(3) of the Constitution. Nor does it require that the procedural and other substantive requirements incorporated into PIE are met. There is furthermore no reflection in this case on the matter of whether the granting of the order is 'just and equitable'. The common law in the form of the rei 
vindicatio may be relevant if the property is used for commercial, industrial or trade purposes. If that had indeed been the case, the application of the common law ought to have been placed into perspective.

\section{Provision of Land and Assistance Act 126 of 1993}

Land was designated in terms of Act 126 of 1993 in the District of Umgeni, KwaZulu-Natal (GN 745 in GG 32396 of 2009-07-17).

\section{Land Titles Adjustment Act 111 of 1993}

Land in the district of Mankwe, North West Province, was designated under the Land Titles Adjustment Act 111 of 1993 (GN 598 in GG 32253 in 2009-0529; GN 842 in GG 32499 of 2009-08-21).

\section{Transformation of Certain Rural Areas Act 94 of 1998}

A notice was published in terms of section 9(1)(a) of Act 94 of 1998 as the date of commencement of the transitional period of 18 months in respect of the farm Genadendal (GN 744 in GG 32396 of 2009-07-17).

\section{Unlawful occupation}

The long-awaited judgment in the Joe Slovo Community case was finally handed down on 10 June 2009, namely, Residents of Joe Slovo Community, Western Cape $v$ Thubelisa Homes, Minister of Housing, Minister of Local Government and Housing, Western Cape; and Curiae Amicae Curiae (CCT 22/08). This particular case was well-covered in the media, especially in the Western Cape Province, after the eviction order was granted in the High Court. In August 2008, the leave to appeal was heard by the Constitutional Court and the judgment was finally delivered in June this year. The format of the judgment is interesting as it embodies five judgments prepared by different members of the Court, namely, Moseneke DCJ, Ngcobo J, O'Regan J, Sachs J and Yacoob J, and they comprise over 200 pages, all in support of the central order. All five judgments agreed that two key legal issues had to be dealt with:

(a) whether the first to the third respondents have made out a case for eviction of the applicants under PIE; and

(b) whether the respondents have acted reasonably within the meaning of section 26 of the Constitution in its attempt to evict the respondents.

Although these issues deal with constitutional matters and although it is imperative that these issues had to be dealt with by the Constitutional Court, the broad spectrum of all five judgments will not be discussed here. As alluded to above, the focus will be on the relevance of PIE, and accordingly the portions of the individual judgments dealing with the unlawful (or lawful) occupation of land will be discussed here. In this regard the particular approach to, and interpretation of, 'consent' was especially relevant. 
The area in question is the Joe Slovo informal settlement located about $10 \mathrm{~km}$ to the east of Cape Town and adjacent to KwaLanga. The area is the property of the City of Cape Town. Occupation of the area started around 1990, whereafter the population of the area grew continuously until 1994, at which time forced removals and demolitions ceased. Under the new political dispensation, the City of Cape Town adopted a more humane approach towards the occupants and started to provide them with water, container toilets, and to number the various structures. Despite consequent negotiations between the City and the occupiers, which led to the improvement of their lives on a daily basis, the particular rights of the occupiers in relation to the area being occupied were never, as such, clarified (para 22). Hence, no rights of occupation were formalized. Although conditions in the area improved, the living conditions were hardly ideal: occupants lived in overcrowded, unhygienic and unsafe conditions. In 2005, the N2 Gateway Project was embarked upon and its main aim was to improve the settlement. The plan was to upgrade the area in three phases, with a spectrum of housing options ranging from low-cost rental housing (between R150-R300 per month) to bonded property. (These amounts later escalated to range from R600 to R1 050 per month.) At some stage during the development, some members of the community were awarded 'red cards' to indicate that the holder thereof had applied for housing with the municipality (para 35). The high court found that, in order for the Project to be completed successfully, the Joe Slovo Community had to be removed and were prohibited from returning to the land. When the High Court eviction order was granted, 4386 households consisting of about 20000 individuals, were affected.

The first issue the judgment deals with, and upon which this discussion is essentially focused, was whether the occupants fell within the ambit of PIE. PIE can only be applicable if the relevant person or persons are unlawful occupiers. In order to be an unlawful occupier, the tacit or express consent to occupy or another right in law to occupy has to be absent. Before this judgment, the content of consent had not been investigated in detail in relation to PIE, although case law exists in relation to 'consent' within the ESTA context (see, eg, Landbounavorsingsraad $v$ Klaasen 20053 SA 410 (LCC)). Judge Yacoob's judgment is the first to deal with 'consent' extensively, resulting in the other judgments commenting on and distinguishing aspects thereof. Judge Yacoob's judgment found that there was never any consent, be it express or tacit. The other four judgments found that consent had been granted, but later revoked on the one hand, or consent had been granted conditionally and later revoked, on the other. All the judgments thus agreed that at the time the eviction proceedings were lodged, all of the occupants were indeed unlawful in their occupation.

In short, concerning the facts of this case, the respondents argued that there had never been consent, in any form, granted to the occupants, but that the City merely acted from humanitarian considerations (paras 39, 47). The 
appellants, on the other hand, contended that they did have the City's consent - either express or tacit (para 37). In this regard they relied mainly on Rademeyer $v$ Western Districts Council (1998 3 SA 1011 (SECLD)) where it was decided that the city council, by providing services, had granted tacit consent. This argument was further supported by stressing the award of red cards to certain occupiers, and that the City refrained from ejecting them and that assistance was granted after a fire caused severe damage to the area.

Yacoob $J$ approached the issue of consent on the following basis: that consent, in any form, would result in a defensible right of occupation (para 51). The question before the Court was thus whether the occupiers had a defensible right against an eviction application. Accordingly the content of 'consent' was analysed. Consent results in an agreement, thereby implying something bilateral. With reference to the Landbounavorsingsraad case, a decision of the Land Claims Commission by Gildenhuys $\mathrm{J}$, in which the interpretation of 'occupier' was dealt with, it was confirmed that two parties were involved in granting and receiving consent and that a legal nexus had to be created before one can speak of 'consent'. That case did not deal with tacit consent. Judge Yacoob confirmed that, in relation to tacit consent, an agreement was still required - the difficulty was that it had to be proven. Evidence must be such that no other inference can be drawn from it other than that consent was given (para 58). However, if more than one inference is possible, no tacit agreement has been reached. In this regard the 'applicants did not put any evidence of tacit consent before us nor did they rely on estopple' (paras 60, 73). Judge Yacoob rejected the argument that a broad approach to consent had to be followed in order to protect persons falling within the ambit of PIE (para 60). For this purpose he relied on underlying reasons for promulgating PIE and meeting Constitutional imperatives (para 63 and further) and emphasised that PIE already has substantive and procedural protective measures (para 68).

Judge Yacoob was satisfied that no express consent was granted. Whether tacit consent was indeed granted is dealt with in detail in paras 72-83. In order to do that, he proceeded to determine whether the most plausible inference from all of the evidence would indeed be that tacit consent was granted (para 74). The evidence of the Mayor of Cape Town formed the basis of this approach. As alluded to above, her evidence was that no consent was granted, but that the City assisted the occupiers for humanitarian reasons only. Secondly, the constitutional duties of the City were emphasised: the City was enjoined by the Constitution to assist the community - it was their duty (paras 75,79 ). The provision of services did not coincide with the concession of rights (para 78). Accordingly, to merely allow persons to occupy property, with the corresponding provision of support and services, does not indicate consent as such - especially if the point of departure is that there was never an intention to grant consent.

Judge Moseneke dealt with the issue of unlawful occupation in para 141 and further. His point of departure was that 'consent' in section 1 of PIE 
was cast in wide terms with an explicitly broad tenor, but that it had to be interpreted in a manner consistent with the broader purposes of PIE, as well as in light of the spirit, purport and objects of the Bill of Rights (para 146). In this regard Judge Moseneke highlighted two considerations: (a) within the specifically South African context of homelessness, the right to occupy would ordinarily not be evidenced by express agreements or formal resolutions of public entities, but rather by the tacit acquiescence of the owner; and (b) where occupants occupied land belonging to the state, different and more stringent considerations might apply given the obligations under section 26(2) of the Constitution (para 148). Moseneke $J$ differed from Yacoob $\mathrm{J}$ in finding that, on the surrounding facts seen as a whole, a reasonable inference was that the City, as owner of the land, gave the applicants its consent to occupy the settlement (para 149). For this purpose various factors were considered. Some of the residents had been on the land for about 15 years. During that period the City took various steps to acknowledge and accept their occupation - for example, by refraining from ordering the residents to leave the area. Concerning the contention that the mere provision of services would amount to consent, Moseneke $\mathrm{J}$ found that the provision of services to the occupiers was indeed legitimate evidence of the City's state of mind. Hence, the provision of services, taken together with other factors, led to irresistible inference that the City had tacitly given its permission for the occupation (para 155). He thus found that the occupiers occupied Joe Slovo with consent of the City (para 159). Evidence before the court was that there was no formal termination of rights thereafter. However, at the stage the eviction proceedings were lodged, negotiations regarding the N2 project had progressed to such a point that the residents were well aware that they would have to relinquish their homes at some stage. The termination of their rights was therefore also implicit (para 160). In this regard the City was empowered to employ section 6 of PIE to initiate eviction proceedings. The Moseneke judgment thus found that the occupiers had implied consent to occupy, whereafter consent was implicitly terminated. The approach to consent of both Yacoob and Moseneke $\mathrm{JJ}$ is very similar.

In the judgment of Ngcobo $\mathrm{J}$ it is agreed, with Yacoob J, that the mere performance of constitutional obligations by the City did not, without more, constitute consent to occupy (para 211). If that indeed was the case, local authorities and municipalities would be very hesitant to render services to communities in a similar position. Judge Ngcobo further emphasised that in cases like these where persons had to be removed in order for upgrading to take place, the definition of 'unlawful occupier' did not address the real problem (para 216). Instead, the true question was thus not whether the occupiers were unlawful, but rather whether it was just and equitable and in the public interest to relocate them. For this reason Judge Ngcobo had grave doubts as to whether section 6 was indeed the correct vehicle to effect the relocation. 
Judge O'Regan addressed the issue of whether the occupiers were unlawful in para 217 and further. She was not persuaded that the mere rendering of services would constitute consent (para 276) and reiterated the findings of Judges Yacoob and Ngcobo that local authorities and municipalities were enjoined by the Constitution to perform these duties. In order to give rise to an inference of tacit consent, local government would have to do more than merely provide services. Accordingly, each case would have to be considered on its own merits and particular facts. Judge O'Regan was convinced that the municipality went beyond its Constitutional obligations in providing services by taking significant steps to upgrade the settlement after 2002 - so much so, that 'the City was consenting tacitly to the occupation of Joe Slovo' (para 278). That consent was, however, neither permanent nor indefinite, but limited: the City consented to the occupation until it would be necessary for the occupiers to move to make way for the new housing project (paras 280, 290). As the consent was limited (or conditional) it was not necessary for the City to give formal notice to its occupiers of the termination of consent. Once the project got underway, the consent of the City was terminated, rendering the occupiers unlawful within the meaning of PIE.

Judge Sachs disagreed with Yacoob J concerning consent and agreed with Moseneke DCJ, Ngcobo J and O'Regan J that the occupiers had consent and that for the period of 1994-2006 the residents in Joe Slovo were lawful occupiers (para 358), but emphasised that the consent was neither unqualified nor irrevocable. In this regard the conditional character of the consent granted was underlined (para 359). Undisturbed occupation would only be possible for as long as the land was not needed for any other legitimate council purpose.

The application for leave to appeal was granted and the appeal succeeded in part. The residents of the Joe Slovo Community were ordered to vacate the premises in accordance with a timetable set out in the judgment. The relocation order was conditional upon the following: (a) that temporary residential units situated in Delft (or in another appropriate location) had to provided; and (b) that the applicants and the respondent had to engage meaningfully (until 200906-30) with each other with a view to reaching agreement regarding the date when relocation had to start and to a timetable different to that incorporated in the judgment. Following agreement, the Court could issue an order to that effect. The provision of alternative accommodation in the form of temporary residential units was especially elaborated on in the order. Accordingly, the size, the location, and the building materials to be used were prescribed. Further details included reference to the provision of electricity, the location of communal ablution facilities as well as the provision of water and reasonable provision of toilet facilities with water-borne sewerage. A detailed exposition of the meaningful engagement that had to precede every relocation, was furthermore included. The provision of assistance as regards the relocation was also provided for. The residents were interdicted from returning to the area 
and/or erecting further informal structures in the relevant area. To this end informal structures had to be removed by the former occupants and the respondents were authorised to demolish any remaining housing or structures.

The in-depth analysis of 'consent' is welcomed. The court is divided on the matter of whether the occupiers had consent to occupy or not, although all five judgments confirm that, at the time the eviction proceedings were initiated, all of the occupiers were indeed unlawful occupiers. In this regard the four judgments in favour of (tacit) consent will go some way to setting guidelines in relation to tacit consent for future reference. On the basis of unlawful occupation being confirmed, the application of PIE in these circumstances was therefore accepted unanimously, although Judge Ngcobo did voice some concerns as to its real suitability in instances where persons had to be removed to make way for housing development.

In Occupiers of Erf 101, 102, 104 and 112, Shorts Retreat, Pietermaritzburg $\checkmark$ Daisy Dear Investments (case no 245/08 (SCA) decided 2009-07-03) the importance of joining local authorities in eviction cases under PIE was again underlined. In this appeal the eviction order that was initially granted was set aside and instead, a joinder was ordered and a structured interdict was provided for. The latter provided, inter alia, that the Municipality had to confirm on affidavit what steps it has taken and intended to take in its endeavour to provide alternative land for the community involved. Time frames were also required, as the municipality had to indicate when the necessary steps would be taken and at what stage the land will effectively be available. Mediation, as in the Joe Slovo case, was not specifically ordered, although the matter was postponed sine die, for consideration of the matter, including for the possibility of mediation. The matter was finally remitted to the court a quo for its further conduct.

In Voster $v$ Van Niekerk, Van Niekerk en Enige ander onregmatige okkupeerders welke gevind mag word op eiendom bekend as Saffierstraat 6, Jordania (case no 6723/2008 (OFSPD) decided 2009-02-05) an eviction application was dealt with under section 4 of PIE. The exposition of facts is long and complicated; dealing with claims instituted previously, maintenance disputes and various attempts to settle. The property currently being occupied, allegedly unlawfully, belongs to the applicant. The occupier is the applicant's maternal grandfather and his wife. The respondent claimed that he was not an unlawful occupier as he had a usufruct (lewensreg) in relation to the house (para 5). Without an exposition to that effect, the court per Kruger J accepted that PIE was applicable (para 9) and accepted that a possible dispute of facts might exist regarding the existence of a settlement agreement to vacate the property. The court finally reached the conclusion that the application could not succeed as the respondents were elderly persons and section 4(7) specifically required that the rights and interests of the elderly had to be considered (para 12). The respondents are 92 and 83 respectively. The chances of a court granting an eviction order against two such elderly persons are slim indeed. There was, however, 
no balancing of rights and interests in the judgment at all. There was furthermore no reference to any other relevant circumstances (eg, the rights of the landowner), or whether other suitable accommodation, (such as a care facility in light of the age of the respondents) was available.

The question as to whether the granting of an eviction order was 'just and equitable' was also the crux in Wine $v$ Zondani (case no 2044/08 (SECLD) decided 2009-02-27). The respondent is and has been in occupation of a house since 1991. She bought the house with the help of a Standard Bank loan by fraudulently using someone else's payment slip to secure the loan. Her partner at that stage, Mr Oliphant, assisted her in this venture, resulting in the house finally being registered in Mr Oliphant's name in 1992. Since 1991, the respondent had been paying the bond instalments directly into the Standard Bank account. In 2003 the respondent entered into an agreement with the bank to purchase the property. The agreement, acknowledging that the respondent was in possession of the house, identified a firm of attorneys that would effect registration in the name of the respondent. Since 2003, she waited for the firm to contact her to start the registration process while still paying her instalments until January 2005. She was then informed that the house would be transferred free of charge in terms of a government housing programme. During this time she also continued to pay rates and water until early 2008 when she was informed that her details no longer appeared in the municipality's system. Quite unexpectedly a letter arrived February 2008 claiming her vacation of the house. Up to that time she had still contributed to the purchase price and paid rates and utilities.

It later transpired that already in 1995 (4 years after purchasing the house), an action was instituted against the registered owner, Mr Oliphant, by Standard Bank which resulted in a default judgment in favour of the bank. This led to the property being attached and sold by public auction in July 1991. It was bought by Standard Bank for R1 and was transferred to the Bank on 30 August 1995. All of this took place without any notice to the respondent and with her remaining in occupation of the house, still contributing to the initial bank loan and paying rates and utilities! In April 2007, the house was sold to Mr du Preez who sold it in October 2007 to the applicants who then lodged eviction proceedings against the respondent. Standard Bank had continued to accept instalments on the bank loan until 2005, and still had the purchase agreement which was concluded in 2003.

The court per Jansen J confirmed that the applicants were indeed the owners of the house in question ( $p 8$ ) and that the real question before the court was whether an eviction order could be granted. In order to reach that conclusion, the court had to decide whether it would be 'just and equitable' to do so. The court took account of the following: that the registered owners, to some extent, created their own predicament by not inspecting the property beforehand and not ascertaining the respondent's occupation and that there were remedies available to them, and that the bank also played a role in the predicament in 
which the respondent found herself. The court reached the conclusion that in these particular circumstances it would not be just and equitable to grant the eviction order ( $p$ 11).

Ekurhuleni Metropolitan Municipality $v$ Dada and Six Other Respondents (case no 280/2008 (SCA) decided 2009-03-07) dealt with an order granted by Cassim AJ in the a quo judgment that the municipality had to purchase the parcel of land that was occupied unlawfully. The SCA's point of departure was that judges, in exercising their judicial function, were themselves constrained by the law (para 1). The facts were briefly the following: about 76 families unlawfully moved onto privately owned land in the bona fide belief that they had authority from an official of the municipality to do so. The municipality was joined in the proceedings after which relief in the form of a declaratory order concerning the municipality's constitutional obligations, also linked with a time period for report, was sought. In response, the deponent of the municipality dealt in detail with the statutory framework and its administrative and other responsibilities in this regard. The contention was that these statutes, policies and plans represented an ordered, properly prioritised, progressive policy to achieve the objects of the Constitution (para 5). Cassim J, presiding in the court a quo, furthermore required evidence from the municipality concerning its efforts and conduct regarding the occupiers for the period of 20 months that has lapsed since the eviction application was lodged and the hearing began.

By studying the court record, however, the appeal court per Hurt AJA (with Harms DP, Brand, Mhalantla JJA and Bosielo AJA concurring) found that the judge a quo had already, on the second day of the hearing, decided that the municipality ought to purchase the land being unlawfully occupied at a price of R250 000 as the questioning and discussion in the court record indicated (para 8). In the judgment handed down by the court a quo much was made of the inactivity of the municipality regarding the plight of the occupiers, especially regarding the period that lapsed since the application was lodged and the hearing thereof. Reference was then made to judicial deference consisting of a judicial willingness to appreciate the legitimate and constitutionally-ordained province of administrative agencies, to admit to the expertise of these agencies in policy-laden or polycentric issues and to accord due respect to their interpretation of fact and law (para 10). Furthermore, judges should not use the opportunity of scrutiny to prefer their own views as to the correctness of the decision and thus obliterate the distinction between review and appeal - para 10). It was found that the judge a quo failed to have regard to these precepts (para 11): 'The judge was perhaps right in coming to the conclusion that the municipality had not dealt with the problems of the informal settlement on the property with the measure of alacrity which could reasonably be expected of them. But that did not justify his adopting a solution which was well outside the limits of his powers ... The order that the municipality should purchase the property was plainly not "appropriate relief”' (para 14). 
In the PE Municipality decision handed down by the Constitutional Court (CC) in 2005, Sachs J emphasised the duty on courts to seek case-specific solutions in cases of unlawful occupation. He furthermore stated that ' $t$ the way in which the courts are to manage the process has, accordingly, been left as wide open as constitutional language could achieve, by design and not by accident, by deliberate purpose and not by omission' (para 21). In this endeavour, '[the] managerial role of the courts may need to find expression in innovative ways' (para 23). Thus the active questioning of the officials by the presiding judge in the court a quo cannot per se be faulted, especially if it was part of the process of establishing the relevant factors to be considered in order to reach a case-specific, innovative solution. Seemingly the best approach is to find the ideal equilibrium between (a) being actively involved in finding innovative, case-specific solutions, as called upon by the CC; (b) being appreciative of, especially, administrative law considerations; and (c) always being sensitive not to force one's own views on the parties involved.

\section{Housing}

The housing backlog remains a matter of serious concern. Minister Sexwale, during his budget speech of 2009, pointed out that since 1994 approximately 2.3 million houses were allocated which provided shelter to 13 million people. There is still a demand for 2.1 million houses, which will increase towards 2016. One of the priorities of government is to upgrade existing informal settlements in order to address the housing backlog (Anon 'Housing fund shortfall may swell to R102bn by 2012 - Sexwale' Engineering News (2009-06-30) www.engineeringnews.co.za). A United Nations Habitat report indicated that one out of every three houses in South Africa is an informal household (Ndaba 'New agency to focus on land acquisition constraint to housing delivery' Engineering News (2009-04-09)).

The Gauteng Housing Department allocated a R58 million tender to a construction company that has not built a single house in two years. The Department has taken no steps to recover these costs from the company (Legalbrief Forensic (2009-07-16)).

The dispute regarding the transfer of land from the jurisdiction of the Province of the Western Cape to the Housing Development Agency before the 2009 elections still creates problems. The provincial government refuses to transfer the title deeds of 1000 ha of land (Legalbrief (2009-07-22)).

The Social Housing Act 16 of 2008 commenced on 1 September 2009 (Proc 55 in GG 32545 of 2009-08-31).

\section{Land use planning}

A case linked with the regulation of unlawful occupation of land and the development of informal settlements, connected to land use planning in general, is Abahlali Basemjondolo Movement SA v Premier of KwaZulu- 
Natal, MEC Housing and Traditional Affairs KZN, Minister of Housing and Minister of Land Affairs (case no 1874/08 (DCLD) decided 2009-01-27) concerning the constitutionality of the KwaZulu-Natal Elimination and Prevention of Re-Emergency of Slums Act 6 of 1007 (hereafter Slums Act). The attack on the KZN Slums Act was basically threefold, namely:

(a) that the Act essentially regulated eviction, land tenure and access to land and that these matters fell outside the legislative competence of the provincial government,

(b) that specific sections of the Act were in contravention of section 26(2) of the Constitution, and

(c) that the Slums Act was in conflict with the Housing Act and PIE.

Concerning the legislative competence argument, it was stated that the Act essentially dealt with eviction and access to land and sought to regulate tenure. There were, furthermore, certain provisions dealing with eviction that duplicated or overlapped with PIE, regulating standards that overlapped with the National Building Regulations Act, the alignment of policies that overlapped both the national and the provincial Housing Acts and access to housing in general that overlapped with the Housing Act. It was argued that the real purpose of the Slums Act was essentially to eliminate slums and to regulate access to land, a legislative competence assigned only to the national government.

With regard to the second ground it was argued that sections $9,11,12,13$ and 16 were invalid by virtue of their inconsistency with section 26(2) of the Constitution as the Slums Act did not constitute a 'reasonable measure' to progressively realise the right of access to housing (para 7). The measure was unreasonable for many reasons, inter alia, it was in conflict with Chapter 13 of the Housing Code that enables in situ upgrading and discourages eviction (para 7) and it undermined tenure security (para 8). The final ground was that the Slums Act contravened national legislation. Essentially the provisions identified in the second ground above were repeated here with reference to the particular provisions of the Housing Act and PIE which it allegedly contravened (see para 11). Section 16 of the Slums Act was furthermore in direct conflict with PIE as it removed the protection given to unlawful occupiers if landowners tolerated their presence - it instead provided that evictions 'must' take place - para 11). In essence the applicants' case was that if national legislation was in place stating that upgrading had to take place, there cannot be a Slums Act giving municipalities a discretion when to upgrade and when not to; and where there was national legislation placing eviction as a last resort there cannot be a Slums Act stating that evictions 'must' take place (para 26).

On the other hand, the respondents argued that the Slums Act was promulgated to improve the lives of persons living in informal settlements and that accordingly the Slums Act was a reasonable and rational policy. It was also argued that, although the Slums Act was based on the Housing Act, the national and provincial Housing Acts and their constitutionality were never attacked. Regarding the ultra vires argument, it was submitted that 
the Slums Act related to housing and that housing was indeed a concurrent competence of both national and provincial government in Part A of Schedule 4, read with section 104 thereof (para 16).

The second ground of constitutionality was addressed as follows: if all of the sections listed were read in the context of the national and provincial housing laws and policies it became clear that these sections were actually designed to achieve the progressive realisation of the right to access to adequate housing (para 17). Municipalities were furthermore bound by national and provincial legislation and policies and have to take decisions in light of the prevailing framework. Finally it was argued that the third ground of constitutionality, namely that the Slums Act was in contravention with national legislation, also had to fail since the Slums Act specifically incorporated the provisions of PIE (para 22).

The court per Tshabalala JP considered all of the arguments against the backdrop that the right to access to adequate housing was a basic human right and that the living conditions for those who live in slums and slum conditions was a universal problem (para 27). The aims of the Slums Act were set out to be the following: to (a) eliminate slums; (b) prevent the re-emergence of slums; (c) promote the co-operation between the department and municipalities in the elimination of slums; (d) promote the co-operation between the department and municipalities in the prevention of the re-emergence of slums; (e) monitor the performance of the department and the municipalities in the elimination and prevention of the re-emergence of slums; and ( $f$ ) to improve the living conditions of the communities in the province. The sections in issue were sections $9,11,12,13$ and 16 with the last-mentioned the main focus of the application. This section provided that an owner or person in charge must, within a set period of time after publication of a notice in the Government Gazette issued by the MEC, institute eviction proceedings as provided for in section 4 or 5 of PIE (see para 31). The court emphasised that an Act could not be considered piecemeal, but had to be looked at in its entirety (para 32). Consequently the first argument failed.

The second argument, relating to whether the Slums Act violated section 26(2) of the Constitution was similarly rejected (para 36). The court was satisfied that the Slums Act constituted a reasonable legislative measure to deal with the plight of the vulnerable in society. The court held that the third argument that the Slums Act was in conflict with national legislation was unfounded (para 37). There could be no conflict if the Slums Act effectively endorsed PIE and other national legislation. The Slums Act furthermore did not envisage the random eviction of people - all evictions would be carried out with due consideration of whether it was just and equitable to do so (para 37). To bring the point home, the court listed the following additional considerations negating the claim of unconstitutionality:

(a) the Slums Act incorporated PIE and municipalities were made subject to it;

(b) engagement was necessary prior to all evictions taking place; 
(c) the National Housing Code in its entirety was binding on all spheres of government;

(d) section 2(1)(b) of the Housing Act required all spheres of government to consult meaningfully with individuals and communities affected by housing development; and

(e) whilst in situ upgrading was required, it was sometimes necessary to relocate people in order to make way for essential engineering services or where conditions were too hazardous for occupants (para 38).

The application was dismissed, and instead the initiative taken by the provincial legislature of KwaZulu-Natal was applauded.

\section{Deeds}

The Deeds Registries Amendment Bill, 2009, was published for comment (GN 1108 in GG 32497 of 2009-08-17). The purpose of the Bill is to discontinue the possibility of registering mineral rights in a deeds registry (cl 1(a)), and to bring the Deeds Act in line with the Minerals and Petroleum Resources Development Act 28 of 2002. Registrars will in future be obliged to comply with directives from the Chief Registrar of Deeds to ensure uniformity in all deeds registries across the country ( $\mathrm{cl} 1(\mathrm{~b}))$. The full names and marital status of persons will have to be recorded in all documents (other than deeds) that have to be registered, recorded or executed by a Registrar of Deeds (cl 3 amending s 17(2)). Section 34 of the Deeds Registries Act 47 of 1937 is to be amended to allow the issuing of a certificate of registered title to any owner for his or her undivided share in land or fracture thereof (see also the Memorandum to the Bill.)

\section{Sectional titles}

The Sectional Titles Amendment Bill 2009 was published for comment (GN 1109 in GG 32498 of 2009-08-17; see also the Memorandum to the Bill upon which some of the information below is based). The amendments proposed to amend the Sectional Titles Act 95 of 1986 inter alia to provide the agent of a developer, or his or her successor in title, to act on behalf of the developer in respect of the approval of development schemes in terms of section 4 of the Act (cl $1(a)$ to amend ss 10 and $15 B(3)(c))$. Section $1(3 A)$ is amended to delete the reference to section $1(3)(c)$. Section $1(3 \mathrm{~A})$ allows a body corporate to approach the court for relief if a unanimous resolution cannot be reached. However, if a resolution adversely affects a property owner he or she has to consent in writing that the case may be brought to court ( $\mathrm{s} 1(3)(\mathrm{c})$ ). This sometimes results in 'an unreasonable owner' being able 'to hold the body corporate to ransom'. Section 5(4) is amended to read: 'Provided that any window, door or other structure which divides a section from another section of from common property, shall be considered 
to form part of such floor, wall or ceiling' in order to provide more legal certainty as to determining the median line $(\mathrm{cl} 2)$.

In terms of section 4(2), a sectional title register may be opened in respect of more than one piece of land without consolidation of such pieces of land. If one of the pieces is hypothecated under a registered mortgage bond, section 40(5) of the Deeds Registry Act 47 of 1937 will apply. Sections 11(3)(d) and 11(3)(dA) have been inserted to eliminate confusion (cl 3(a)-(b)).

Certificates of real rights of extension and certificates of rights of exclusive use areas will in future have to be lodged in terms of section 25(1) and 27(1) of the Act (s 12 amended by $\mathrm{cl} 4$ ). Clause 5 of the Bill proposes to amend section 14(8) in that it is not necessary to cancel a sectional plan by a court order if the buildings are damaged or destroyed.

Section 24(6)(d) determines that every mortgagee in a scheme should consent when an extension of a section would result in a deviation of more than $10 \%$ in the participation quota of any section. It is not always possible to find all the mortgagees to give consent. Clause 7(b) states that a notice is to be sent to each mortgagee that there will be a deviation of more than $10 \%$ as well as the details thereof. If the mortgagee does not react "within 30 days of the date of posting of the notice, it shall be deemed that the mortgagee does not have any objection to the proposed extension and that the mortgagee consents thereto'. Similarly section 29(3) is amended to provide for 'the obtaining and filing, in the protocol of the notary, of the consent of bondholders that exist on the date of execution of such servitude or agreement' in order to expedite the work of conveyancers and Registrars of Deeds where new servitudes or restrictive agreements need to be registered.

Clause 9(a) of the Bill determines that exclusive use areas depicted in a sectional plan will have to be registered and it will no longer be possible to register sectional plans partially (amending s 27(1)). Exclusive use areas will vest in the body corporate, not only free from any mortgage bonds but also from registered leases, usufruct, habitatio or usus (s 27(4)(b) amended by cl 9(b)). The holders of a registered usufruct, habitatio, usus or lease may in future also consent to the cancellation of an exclusive use area (s 27(5) amended by $\mathrm{cl}$ 9(c)).

Section 37 of the Act is amended to ensure that the developer also contributes to the costs in respect of common property: 'to require from a developer who is entitled to extend the scheme in terms of a right reserved in section 25(1), to make such reasonable additional contribution to the fund as is estimated necessary to defray the cost of rates and taxes ... of the part or parts of the common property affected by the reservation, including a contribution for the provision of electricity and water and other expenses and costs in respect of and attributable to the relevant part or parts' (cl 12(a)).

In Dolphin Whisper Trading 10 (Pty) Ltd $v$ The Registrar of Deeds (Case no 20645/08) (WCHC) decided 2009-03-23) the applicant, a property developer, developed a sectional title scheme in accordance with the provisions of the Sectional Titles Act 95 of 1986 (the Act), which scheme 
was also registered in the Deeds Registry (para 3). It reserved its right, in terms of section 25(1) of the Act, to extend the scheme by the addition of buildings and the horizontal and or vertical extensions of the buildings within a five year period (paras. 9 and 16). The applicant extended a section of the sectional title plan (relating to phase two of the development) in terms of section 24(6) (para 5), and subsequently decided to extend the third and fourth phases of the development in terms of section 25 (instead of $s$ 24(6), which is a cumbersome and expensive process - para 7). Proceeding in terms of section 25 meant that the applicant was not required to get the consent of all the owners and bond holders of the sections in the first and second phases (para 8).

The applicant lodged a batch of documents at the Deeds Registry and applied for the registration of the property developer's plan of extension and the inclusion of certain additional sections in the sectional title register (20). The first respondent rejected the applicant's section 25(9) application on two grounds, namely, that there was a discrepancy between the applicant's certificate of real right and the schedule of conditions in terms of section 11(3) of the Act, and on the basis that the amended participation quota contained more sections than were reflected in the original participation quota (para 15).

The applicant subsequently sought an order to review and set aside the first respondent's refusal to register the sectional plans of extension in the sectional title scheme and to extend the sectional title register in the scheme. The applicant also sought an order directing the first respondent to register certain sectional plans of extension and extend the sectional title register (para 1).

The legal question was whether the first respondent acted unlawfully in rejecting the applicant's section 25(9) application (para 19). Section 25(13) stands central to the issue at hand (para 24). The first respondent refused to register the documents submitted by the applicant on the ground that the applicant failed to erect and divide the building into sections strictly in accordance with the documents submitted in terms of section 25(2) and that the applicant had not established the existence of 'changed circumstances' justifying non-compliance (para 25). The Court found this to be an administrative act and, therefore, reviewable (para 26). The Court, and not the Registrar of Deeds, is in a position to determine whether 'changed circumstances would make strict compliance impracticable' (para 41). The Court stated that '(i)t is correct that in terms of the Act the sections must be divided strictly in accordance with the documents submitted when the right was reserved. Where, however, it is not practicable to do so because of the existence of "changed circumstances" the Court may, on application by a developer, condone non-compliance with the provisions of the Act. The onus is on the developer pleading "changed circumstances" to set out fully facts indicating the nature and extent of the "changed circumstances" relied upon and how they came about' (para 42). 
The applicant contended that changes in the property market conditions constituted 'changed circumstances', but the Court found that the applicant did not present any evidence to indicate why strict compliance was no longer possible or practicable (para 47). The Court also found that the first respondent did not act unlawfully when it refused to register the sectional plan of extension and that the applicant did not comply with the requirements of section 25(13) and did not give a satisfactory explanation for the said non-compliance (para 49). As a result, the Court dismissed the application with costs (para 51).

\section{Minerals}

A group of European investors instituted a claim against the South African government claiming that the Mineral and Petroleum Resources Development Act 28 of 2002 deprived them of their mineral rights without proper compensation. The conversion of old order rights to new order rights also placed additional obligations on the companies, for example, with regard to broadbased Black empowerment as well as environmental plans (Piero Foresti, Laura de Carli $v$ the Republic of South Africa). The case is instituted before an ad hoc arbitration tribunal of the World Bank's International Centre for Settlement of Investment Disputes. The case is postponed until April 2010 (Creamer 'NGOs helping world tribunal to uphold human rights in SA mining legislation' Mining Weekly (2009-07-27) www.miningweekly.com).

\section{Agriculture and rural development}

According to the Medium Term Strategic Framework (MTSF) (A Framework to Guide Government's Programme in the Electoral Mandate Period (2009-2014)) (http://www.info.gov.za/), five objectives are identified that include, among others, the resolve to 'halve poverty and unemployment by 2014; to ensure a more equitable distribution of the benefits of economic growth and reduce inequality and to improve the nation's health profile and skills base and ensure universal access to basic services'. Ten priority areas were identified. Priority 3 sets out the rural development strategy linked to land and agrarian reform and food security. The comprehensive rural development strategy has 10 core elements, namely: (a) aggressive implementation of land reform policies; (b) to stimulate agricultural production with a view to contributing to food security; (c) rural livelihoods and food security; (d) to improve service delivery to ensure quality of life; (f) to implement a development programme for rural transport; (g) skills development; (h) revitalisation of rural towns; (i) explore and support non-farm economic activities; ( $j$ ) institutional capacity development; and (k) cooperative development.

\section{Agriculture}

In the Agriculture Strategic Plan 2009/10 for the Department of Agriculture, 
Forestry and Fisheries (http: //www.nda.agric.za/), five departmental programmes were identified, including production and resources management, agricultural support services, and food safety and bio-security. The Department has seven key result areas. These include amongst others: (a) to ensure the availability of, and access to, sufficient, safe and nutritious food; (b) to eliminate skewed participation and inequality in the agricultural sector; (c) to increase growth, income and remunerative job opportunities in agriculture; (d) to enhance the sustainable and efficient use of natural agricultural resources and production inputs; (e) to ensure efficient and effective governance and partnerships; (f) to ensure knowledge and information management; and (g) to ensure national bio-security and effective risk management.

In addition, the Department identified five priority focus areas, namely the creation of decent work and sustainable livelihoods; education; health; rural development, food security and land reform; and the fight against crime and corruption. The activities of the Department will in the next 5 years focus on speeding up growth, social and economic infrastructure development, rural development (linked to land reform), skills development and the human resource base.

The Department has three core strategies, namely, to enhance equitable access and participation in the agricultural sector; to improve global competitiveness and profitability, and to ensure sustainable resource management. In order to increase the number of black entrepreneurs in agribusiness, accelerate land reform, raise agricultural production, promote trade and provide access to support services (including financial assistance to target groups), the Department will continue to strengthen partnerships with organised agriculture.

The Department of Agriculture's mandate was extended and it was renamed the Department of Agriculture, Forestry and Fisheries. With regard to forestry, the Department aims to make a significant contribution to the so-called Meeting the Basic Needs Programme through the Forestry Livelihoods Programme. In relation to fisheries, the Department aims to continue to promote conservation and the sustainable utilisation of natural (marine) resources. The Department of Rural Development and Land Reform's Comprehensive Rural Development Programme (CRDP) ensures a partnership with the Department of Agriculture, Fisheries and Forestry. The roles of the Department of Agriculture, Fisheries and Forestry are to support the expansion of agrarian reform through the promotion of agricultural co-operatives; to provide technical skills, financial resources and agricultural production enhancing investment; and to provide other services within the Comprehensive Agricultural Support Programme (CASP).

With regard to international relations, the Department makes it clear that it will continue to implement the African Agricultural Development Programme (AADP) through bilateral agreements with a number of African countries. These agreements will focus on the provision of technical assistance to African countries, the transfer of technologies and market access. During the $2009 / 10$ period, the Department will focus on 
accelerating service delivery in all eight departmental priority areas (ie AADP (African Agricultural Development Programme), AgriBEE, CASP (Comprehensive Agricultural Support Programme), IFSNP (Integrated Food Security and Nutrition Programme), KIMS (Knowledge and Information Management Systems), Natural Resources Management and R\&D (Research and Development)).

\section{Rural development}

The Comprehensive Rural Development Programme Framework (http://www .pmg.org.za) is 'premised on a proactive community-based planning approach rather than an interventionist approach to rural development' (Executive Summary). This framework is to be implemented through the coordination of three interlinked focus areas, viz 'a coordinated and integrated broad-based agrarian transformation; strategically increasing rural development; and an improved land reform programme' (Executive Summary).

The agrarian transformation focus has, as its main objectives, livestock farming and cropping as well as the development of their related value chains. The rural development focus aims at the establishment of business initiatives, agro-industries, cooperatives, cultural initiatives, as well as local markets within the rural context; the empowerment of rural communities (especially women and youth); capacity building initiatives in respect of rural communities in order to lessen community vulnerability; and the revitalisation of existing, and the creation of new, economic, social and information infrastructure, public amenities and facilities in rural villages and towns. All three land reform programmes (restitution, redistribution and tenure reform) will be linked to the CRDP. The following priorities have been identified for the land reform focus area: the review of current land reform products and approaches; the review of land acquisition approaches (with specific reference to the willing buyer-willing seller model); the facilitation of secure access to land in the case of people who live on farms; the protection of the land rights of farm labourers; and expediting the finalisation of the restitution programme. Two CRDP pilot projects are currently being implemented: Riemvasmaak in the Northern Cape and Muyexe Village in the Greater Giyani Local Municipality (Limpopo Province).

Willemien du Plessis (NWU (Potchefstroom))

Juanita Pienaar (US) Nic Olivier (UP) 